\title{
A Moderated Mediation Model: Mediating Mechanism of Workplace Incivility and Moderating Role of Islamic Work Ethics between Dark Triad and Organizational Citizenship Behavior
}

\author{
Muhammad Salman Chughtai ${ }^{{ }^{*}}$, Syed Zulfiqar Ali Shah ${ }^{2}$ \\ ${ }^{1,2}$ Faculty of Management Sciences, International Islamic University, Islamabad, Pakistan
}

\section{Keywords:}

Dark Triad, Workplace Incivility, Islamic Work Ethics, Organizational Citizenship Behavior, Theory of Threatened Egotism, Ethical Climate Theory, Public Sector Organizations

\section{Received}

20 August 2020

Received in revised form

30 September 2020

Accepted

19 October 2020

\section{*Correspondence:}

salman.phdmgt80@iiu.edu.pk

\section{ABSTRACT}

The main aim of this study was to examine the impact of the Dark Triad (DT) on Organizational Citizenship Behavior (OCB). The mediation effect of Workplace Incivility (WPI) between the relationship of DT and OCB was also analyzed. Furthermore, the moderating role of Islamic Work Ethics (IWE) was also tested between the relationship of WPI and OCB, in terms of the Theory of Threatened Egotism (TTE) and Ethical Climate Theory (ECT). Hypotheses of this study were tested using data of 326 employees (male/female) working in different public sector organizations (Lahore High Court, Lahore, and Rawalpindi Bench, Advocate General, and Attorney General Office). Data was analyzed by using SPSS 25.0 and Smart-PLS, a direct relationship was tested by using hierarchal regression, the indirect effect was tested by using the methods of Barron and Kenny, Sobel, and Hayes, and moderation effect was tested by using PROCESS-macro. Findings support the hypothesis of this study, as workplace incivility indirectly with the presence of dark personality negatively influence the organizational citizenship behavior of employees. Findings further explore that moderation of Islamic work ethics reduces the strength of the negative indirect effect of dark personality via workplace incivility on organizational citizenship behavior. Investigation of this study contribute to the literature of personality psychology and organizational behavior, by showing that the dark side of personality develops the features of uncivil behavior that reduce the level of organizational citizenship behavior, IWE as a potential moderator provide an ethical climate in the organization that reduces the intensity of these negative behaviors. 
The individual's attitude reveals their conduct at the workplace that further influences individual and institutional efficiency. The personality of each individual is universal and indispensable for individual, group, departmental or organizational achievements (Finkelstein et al., 2009). Dark personalities due to lack of willingness and cooperation create problems valuable relationships at the workplace with management and peers that further provide a foundation for a decrease in individual and organizational performance. In the modern context, the dark side of personalities influences organizational effectiveness (Spain, Harms, \& LeBreton, 2014) and shows discrepancy between the social relationship (O'Boyle et al., 2012; Paulhus \& Williams, 2002; Spain et al., 2014). DT studies evidenced that it is worthwhile concerning with thoughtlessness and aggression (Jones \& Paulhus, 2011; Jones \& Paulhus, 2010), depraved manners, unprofessional workplace activities, and unethical behavior of individuals (Garcia \& Rosenberg, 2016; Kajonius, Persson, \& Jonason, 2015; O’Boyle et al., 2012; Roeser et al., 2016). Additionally, dark personalities empirically and theoretically have three dimensions, such as, 'narcissism', 'psychopathy', and 'Machiavellianism' (Paulhus \& Williams, 2002) that mostly demonstrate high-level discrepancy, disagreeableness, and thoughtlessness at the workplace that further influence the interpersonal relationship and well-being of others (Jakobwitz \& Egan, 2006; Jones \& Figueredo, 2013; O'Boyle et al., 2012; Paulhus \& Williams, 2002).

However, WPI an anti-social behavior which usually focused on a high level of harm aims of individuals i.e., aggression, anger, bullying, deviance, and violence (Douglas \& Martinko, 2001; Glasø et al., 2010; Hershcovis, 2011; Nielsen et al., 2012; Robinson, Wang, \& Kiewitz, 2014; Yen $\&$ Teng, 2013) and that behaviors cause due to negative personality of individuals when they face threat to their ego from others (Baumeister \& Campbell, 1999; Baumeister, Smart, \& Boden, 1996; Bushman \& Baumeister, 1998; Konrath, Bushman, \& Campbell, 2006). Furthermore, Anderson and Pearson (1999) discuss that WPI is a reciprocal procedure where organizational climate threatened the personality identification that forces them to the demonstration of an aggressive and thoughtless act; and these activities become a financial loss for the organizations as proved by Cortina et al. (2001) with a sample of public sector employees. The literature of WPI generally focuses on outcomes and consequences of that malicious behavior (Abrar, Baig, Javed, \& Shabir, 2014; Andersson \& Pearson, 1999; Cortina et al., 2001; Lim et al., 2008; Meier \& Semmer, 2013; Miner-Rubino \& Reed, 2010; Setar et al., 2015), but research is scarce where antecedents of WPI discussed. Recent scholarly work discusses the social, psychological, economic, and financial consequences of WPI that harm the interpersonal relationship of employees and organizational outcomes (Bai, Lin, \& Wang, 2016; Porath \& Pearson, 2013; Sguera et al., 2016). According to Anderson and Pearson (1999), the climate of the organization also spirals the individuals for WPI, whereas the ethical climate of an organization derived from codes, norms, contextual and organizational factors that further optimize the positive organizational outcomes i.e., commitment, OCB, and job satisfaction (Martin \& Cullen, 2006; Victor \& Cullen, 1987, 1988).

Islam has provided ethics and values that operate an ethical atmosphere that encourages positive behaviors and friendly interpersonal relationships. IWE derived from the 'Holy Quran', 'Sunnah of MUHAMMAD (SAW)', and the practical life of his first four companions (R.A), as the strong perception about the ethics of Islam provides a better ethical climate, where individuals positively perform their responsibilities, with cooperation, dedication, coordination and with commitment (Ali, 1992; Khan et al., 2015). Uncivil behavior in the workplace affects the different individual and organizational outcomes (Hershcovis, 2011; Liu et al., 2018; Schilpzand, De Pater, \& Erez, 
2016; Sguera et al., 2016; Welbourne \& Sariol, 2017). Islamic ethical climate can reduce malicious behavior, which causes to threat to the ego of negative personality individuals. OCB is generally discussed about the positive behaviors of individuals that they perform and are not directly required by the organization, nor any direct reward system supports that behaviors but are beneficial for the planning of smooth functioning (Organ, 1988). Moreover, the theory of threatened egotism (Baumeister et al., 1996; Bushman \& Baumeister, 1998) clarifies that due to threat to the ego of dark personalities from others at the workplace i.e., peers and supervisors due to this they react with uncivil behavior.

The theoretical foundation of the present study is based on the integration of the theory of threatened egotism (TTE) (Baumeister et al., 1996; Bushman \& Baumeister, 1998) and ethical climate theory (ECT) (Victor \& Cullen, 1987, 1988). Through which we investigate the influence of adverse personality effects on OCB and explains the mechanism of WPI as a mediator (Liu et al., 2018; Özsoy, 2018; Schilpzand et al., 2016; Webster \& Smith, 2019) to find out the sources of uncivil behavior of individuals at the workplace as called by (Chen \& Wang, 2019; Liu et al., 2019). Moreover, we examine the moderating role of IWE as an ethical factor (Turnipseed \& Landay, 2018) to narrow down the gaps, as suggested in recent previous studies. Theoretically, this study contributes to organizational behavior and personality psychology literature by explaining the relationship between DT, WPI, and OCB. Secondly, our work contributes with the explanation of the intervening mechanism of WPI between DT and OCB, thirdly our study explores the moderating effect of IWE, as Islam has strong ethical roots for humanity, without any discrimination of color, region, religion, and race; this explains how Islamic ethical code of life should reduce the negativity of personality and uncivil behavior of individuals at workplace.

\section{Theoretical Foundation and Literature Review}

The theoretical foundation of the present study lies on TTE (theory of threatened egotism) (Baumeister \& Campbell, 1999; Baumeister et al., 1996) and ECT (ethical climate theory) (Victor \& Cullen, 1987, 1988) which explains that individuals feel a threat to their ego at the workplace from their colleagues and supervisors that contribute for the cultivation of uncivil behavior which resulted in diminishing positive behaviors i.e., OCB. In contrast, ECT (Victor \& Cullen, 1987, 1988) explains that if organizations provide an ethical climate in the form of culture, norms, rules, and policies that would reduce the negative intensity and uncivil behavior of employees. The working environment of public sector organizations in developing countries threaten the inflated self-esteem of dark personalities, which resultantly react with negative emotions and attitudes (Costello \& Dunaway, 2003) i.e., anger, that decrease OCB and increase WPI (Brender-Ilan \& Sheaffer, 2019; Hart, Adams, \& Tortoriello, 2017; Penney \& Spector, 2002). ECT (Victor \& Cullen, 1987, 1988) discusses the ethical climate of the organization which influences the commitment, well-being, satisfaction, and attitudes of individuals (Martin \& Cullen, 2006); as a result, it improves the positive behaviors, morality, and responsibility level of employees and reduces the negative behaviors i.e., aggression, anger and egoism and emotional exhaustion (Yang Tsai, \& Tsai, 2014). Dark personalities have high inflated self-esteem, and because of this, they are more worried about encouragement from their colleagues and supervisors so that they can tolerate and maintain their inflated self-esteem and ethical climate of the organization (Öngen, 2010) and interpersonal relationships as well (Wang \& Hsieh, 2013). Based on the above discussion of theoretical conceptualization, we proposed a conceptual model for this study. 


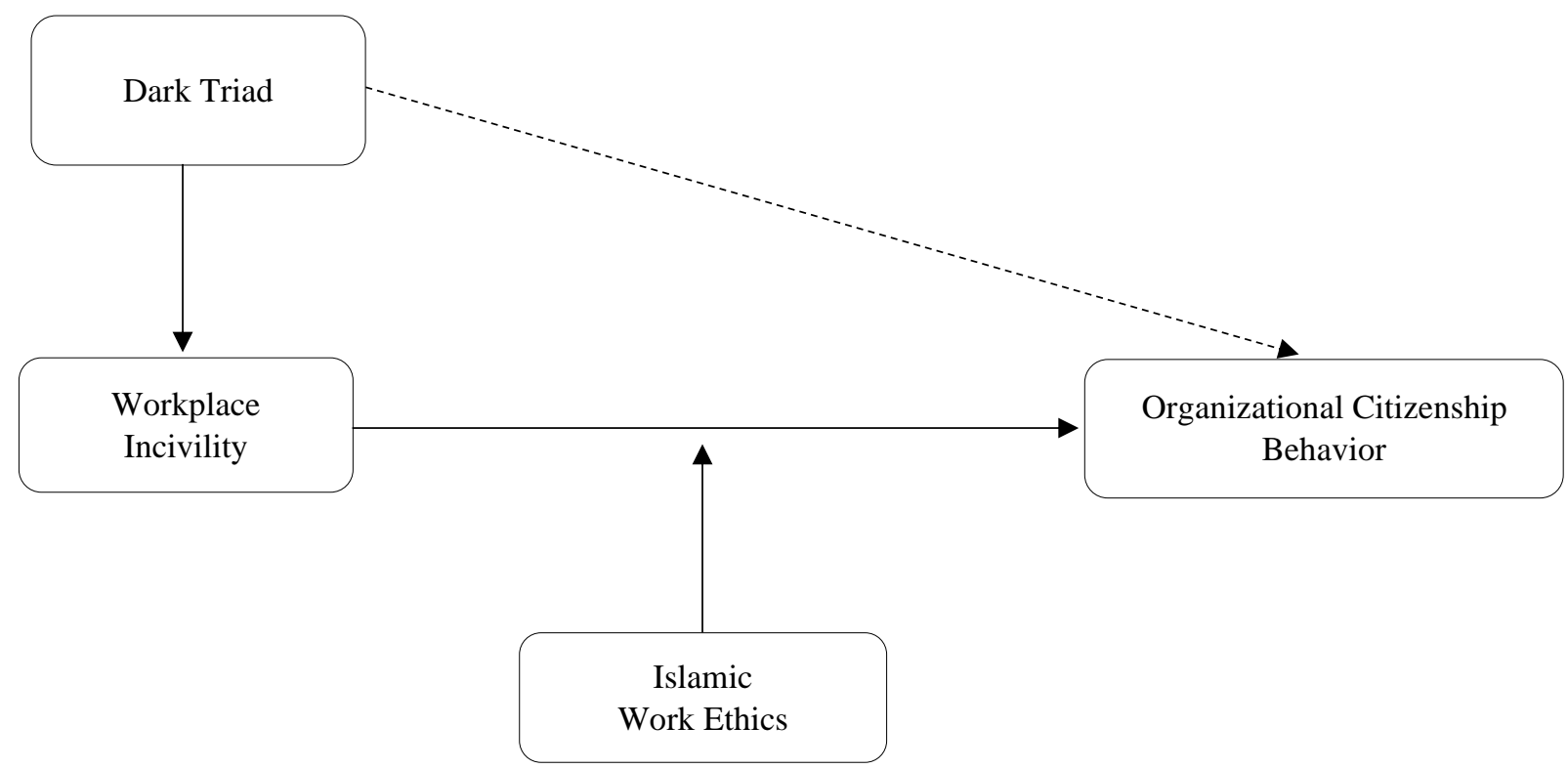

Figure 1. Research model

\section{Dark Triad and Organizational Citizenship Behavior}

Dark triad has profound impacts on administrative and individual consequences at the workplace, as it is a collection of different dark human characteristics i.e., 'narcissism', 'psychopathy', and 'Machiavellianism' (Jonason, Wee, \& Li, 2009; Jonason et al., 2012; Jonason \& Webster, 2010). The category psychopathy involves egoistic and disappointing interpersonal contact, lack of feelings, and immature behavior (Boey \& Vantilborgh, 2016). These individuals show low identity desires and apprehension, impulsivity, lack of responsibility and sensitivity (Brankley \& Rule, 2014; Cohen, 2016; Jones \& Paulhus, 2010; Paulhus \& Williams, 2002) that produces adverse outcomes i.e., proud and egotistic behavior in social relations at the workplace (Jakobwitz \& Egan, 2006). Narcissist personalities are unique as they perceive the sense of supremacy, authority, and dominant position over others (Furnham, Richards, \& Paulhus, 2013; Jonason et al., 2015; Paulhus $\&$ Williams, 2002). Therefore, they demonstrate their behaviors through their activities to get the attention of others (Jakobwitz \& Egan, 2006), with the use of harmful tactics to strengthen their position with a sense of egoism, impressiveness (Mathieu, 2013; Öngen, 2010). These personalities always want to become a central point of team/group by using different negative strategies i.e., selfenhancement or looking for the politeness of others (Morf \& Rhodewalt, 1993, 2001; Paulhus \& Williams, 2002). Machiavellianism is concerned with individual's devious strategies of communication with others to enhance attraction in the society, and at the workplace as well regarding their personality (Jonason et al., 2009; Jonason \& Webster, 2010; Paulhus \& Williams, 2002). Therefore, these personalities try to defeat others for benefits i.e., authority, supremacy, prominence and financial benefits, from that exploitation (Jakobwitz \& Egan, 2006). These personalities do not feel any shame by using unethical tactics, with the quality to discourage others i.e., abusive supervision, so that they can get benefits from disadvantages of others (Furnham et al., 2013; Paulhus \& Williams, 2002; Wisse \& Sleebos, 2016).

Individuals having a dark personality are not most suitable for the accomplishment of citizenship behaviors, as several meta-analysis and reviews of the literature emphasize on how dark features of personality negatively related to the positive attitude and effectiveness of employees (Mathieu, 
2013; Mathieu et al., 2014; Michel \& Bowling, 2013; Smith et al., 2016; Smith \& Lilienfeld, 2013; Webster \& Smith, 2019; Wille De Fruyt, \& De Clercq, 2013). Few empirical studies evidenced the link of DT with positive behaviors of individuals at the workplace and found a negative association between dark personalities and OCB (Becker \& Dan O'Hair, 2007; Blair, Hoffman, \& Helland, 2008; Judge \& LePine, 2007; Judge et al., 2006; Schütte et al., 2018; Spain et al., 2014) and some studies found no relationship between DT and OCB (Dahling, Whitaker, \& Levy, 2009; Webster \& Smith, 2019). In contrast, OCB is flexible and societal behavior that gives others importance over oneself (LePine, Erez, \& Johnson, 2002; Organ, 1988, 1997). It is observed that a person high in DT gives less importance to engage in OCB. The high level of sovereignty desires of Narcissists and Psychopathic (Paulhus \& Williams, 2002; Raskin \& Hall, 1979) personalities prevents them from engaging in optional facilitating manners i.e., OCB. Moreover, Machiavellians usually emphasize to prioritize themselves, even at others' cost, and they may likely less engage in OCB (Dahling et al., 2009; Jones \& Paulhus, 2009). In contrast, individuals high in Machiavellianism seems to show higher levels of exciting OCB in two situations; when they observe that their leader is transformative and in the existence of a favorite transactional psychological contract (Belschak, Den Hartog, \& Kalshoven, 2015; Zagenczyk et al., 2014) and other dimensions of dark personalities i.e., narcissists and psychopaths involve in less OCB (Smith et al., 2016) than others low in these traits. Based on the above discussion of literature we hypothesize:

H1: DT is negatively associated with OCB.

\section{Workplace Incivility as Mediator}

WPI is a different construct from aggression, mistreatment, and insulting supervision behavior (Hershcovis, 2011). Incivility at the workplace is generally concerned as a desecration of workplace rules/norms and reciprocated respect (Andersson \& Pearson, 1999) that harms the interpersonal relationship. In contrast, OCB is concerned with individuals' behavior that is not required by the organization in form of their duties. However, individuals perform these positive behaviors at the workplace for their organizations, which can also be beneficial for interpersonal harmony and enhancement of individuals' performance (Mackenzie, Podsakoff, \& Podsakoff, 2018; Organ, 1988). Additionally, these positive behaviors are affected by individuals when they face hostile interpersonal relations and behavior (Liu et al., 2019) in the form of WPI. Literature is insufficient on WPI and OCB, but some recent studies provide evidence about the negative influence of WPI on OCB (Karatepe, Kim, \& Lee, 2019; Mao et al., 2019; Porath \& Erez, 2009; Rhee, Hur, \& Kim 2017; Schilpzand et al., 2016), findings of these studies stated that uncivil behaviors of individuals in the form of poor communication, lack of self-respect to peers and supervisors, lack of resources to fulfill the requirement of job responsibilities that further affect the positive outcomes i.e., individuals' performance and OCB. On the other side, Liu et al. (2019) asserted that no significant relationship was found between WPI and OCB.

Andersson and Pearson (1999) asserted that discourteous conduct at the workplace can be explained as rudeness, lack of respect for others, and impoliteness. Moreover, violence, anti-social behavior, apparently harmful intentions also linked with WPI (Pearson et al., 2001). Additionally, WPI caused of displeasure, sadness, hopelessness, nervousness, workplace loneliness, and annoyance (Cortina \& Magley, 2009; Pearson et al., 2000; Pearson et al., 2001) that affects an individual's performance, commitment, satisfaction, and OCB as well (Chen \& Wang, 2019; Lim et al., 2008; Pearson \& Porath, 2005). Researchers report that WPI causes unpleasant moralities at 
the workplace that disturbs the individuals' psychological and physical health, professional efficiency, and organizational outcomes (Akella \& Lewis, 2019; Bunk \& Magley, 2013; Lim \& Cortina, 2005; Lim, Cortina, \& Magley, 2008) that resulted into reduction in satisfaction level (Chen \& Wang, 2019) organizational commitment level (Pearson \& Porath, 2005; Porath \& Pearson, 2013) OCB (Mao et al., 2019) creativity and team spirit (Porath \& Pearson, 2013) destruction of workplace ethics and low level of appreciation for others (Hur, Kim, \& Woo, 2014) workplace abnormality, psychological distress, high level of anxiety that affect work quality level (Bai et al., 2016; Lim et al., 2008). Moreover, Pearson et al. (2005) stated that WPI occurs in individuals due to pressure of work and rapid organizational strategies. In contrast, Lane and McCourt (2013) asserted that WPI also occurs due to a change in norms, cultures, and context. Karim et al. (2015) disclose that positive relationships between EI and work-related outcomes were mediated by WPI. Based on the above discussion of literature we hypothesize:

$\mathbf{H}_{2}$ : WPI is negatively associated with OCB.

H3: WPI mediates the relationship between DT and OCB.

\section{Islamic Work Ethics as Moderator}

Ethical rules of Islam for personal, social, and professional life derived from the 'Holy Quran', 'Sunnah of the Prophet MUHAMMAD (SAW)', and from the heritage of Islamic Caliphs (Ali, 1992; Ali \& Weir, 2005; Rizk, 2008) and these ethics mirrored as a consequence of faith for all domains of life (Rashid \& Ibrahim, 2008; Sehhat, Ashena, \& Parsa, 2015). Moreover, cultural context and religiosity also affect the meaning of business ethics (Rashid \& Ibrahim, 2008). Literature shows that religion influenced the attitudes and behaviors of persons (Weaver \& Agle, 2002). Those individuals who hold strong faith in religion are more disciplined and responsible with a higher ethical value (Wiebe \& Fleck, 1980). Islamic work ethics and Protestant work ethics are the central ethical schools that emphasize doing hard work with dedication, cooperative behavior with peers at the workplace, and evading the use of every immoral and discourteous approach of wealth gathering (Yousef, 2001). Islamic ethical teachings give importance to teamwork and dialogue at the workplace with others as a procedure to avoid mistakes and complications faced by others (Ahmad, 2011; Khan \& Rasheed, 2015) during the process of the task assigned by the management of the organization. Components of IWE i.e. fairness, ethics, kind-heartedness, and faith raise the intrinsic motivational level of individuals (Gheitani et al., 2019; Nasution \& Rafiki, 2019) that reduce the negative inner emotions i.e. threat of ego, dislikeness of others. Numerous studies discussed the moderation effect of IWE in different regional (Pakistan, Nigeria, Malaysia, UAE, Iran, Indonesia) and organizational contexts (public and private sectors) with different variables (Ahmed et al., 2019; Annisaa Miranty \& Wimbarti, 2014; Chughtai, 2017; Javaid, Abdullah, Zeb, \& Hussain, 2018; Kareem \& bin Azmin, 2018; Shamsudin, Rahman, \& Romle, 2015). To overcome the gap suggested by Shin and Hur (2019), there is a need to test potential moderation effects between the relationship of WPI and employees' outcomes; thus, we use IWE as a moderator to narrow down that suggested research gap.

H4: IWE moderate the negative relationship between WPI and OCB in the sense that a higher level of IWE moderate (weaken) the negative relationship between WPI and OCB.

H5: IWE moderates the indirect effect of DT on OCB via WPI in the sense that a higher level of IWE will weaken the indirect effect of DT. 


\section{Method}

\section{Data Collection, Population, and Sampling}

The data was comprised of permanent employees of public sector organizations (Lahore High Court, Lahore, Rawalpindi, Advocate General Office, and Attorney General Office). Purposive sampling technique was used in this study as this study assist researchers regarding the information required for the research from the persons who willingly agree to participate in the study so that they can provide their opinion about the explanation of phenomenon (Bernard, 2017; Etikan, Musa, $\&$ Alkassim, 2016). Through the self-administered mechanism of data collection, the data was collected from the participants in two different temporal separated periods. For that purpose, in the first time-lag opinion of participants collected about dark triad (independent variable) and workplace incivility (mediating variable). In the first span, 500 close-ended questionnaires were distributed to participants and 410 questionnaires were received at the end of the first span that further circulated to those participants whose questionnaires were completed at the end of the first time-lag. In the second span, opinion of participants collected about Islamic work ethics (moderating variable) and organizational citizenship behavior (dependent variable), and final questionnaires which received at the end of the second span was 326, according to this, response rate was $65.2 \%$

\section{Research Tools}

Instruments for data collection of this study were used from the earlier published research studies and items of all scales were measured on a five-point Likert scale which was ranging from '1Strongly Disagree' to '5-Strongly Agree. Dark Triad consists of three human behaviors (psychopathy, narcissism, and Machiavellianism), 27 items scale (09-items for each human behavior, three items from each human behavior removed which was not matched with the social context of the study) was taken from Jones and Paulhus's (2014) study, to measure the personality of individuals. Organizational citizenship behavior was measure by taking the 9-items scale of Lee and Allen's (2002) study, Workplace incivility was analyzed through the 7-items scale of Cortina et al.'s (2001) work, and Islamic Work Ethics (Self-Discipline and Patience) was measured through the 12-items scale adopted form Wahab, Quazi, and Blackman's (2016) study.

\section{Results}

In total, $85.28 \%$ (278) of the participants were males and $14.72 \%$ (48) were female; $46.63 \%$ (152) respondents belonged to the age category of 20-30 years, $38.04 \%$ (124) respondents were from the age group of 31-40 years; 50\% (163) participants held the 'master's degree' and $22.09 \%$ (72) held the degree of 'graduation'. Experience-wise, 27.3\% (89) had experience of 'less than one year', $24.54 \%$ (80) fell in the category of ' $1-5$ years' experience, and $15.95 \%$ (52) had experience of ' 11 15 years. Additionally, 36.2\% (118) participants were employees of 'Lahore High Court, Lahore', $27.3 \%$ (89) participants were employees of 'Lahore High Court, Rawalpindi Bench', 19.33\% (63) participants were employees of 'Advocate General Office' and 17.18\% (56) participants were employees of 'Attorney General Office'. Figure 2 presents the fitness of the model, which shows that all variables were statistically and significantly correlated with each other. 


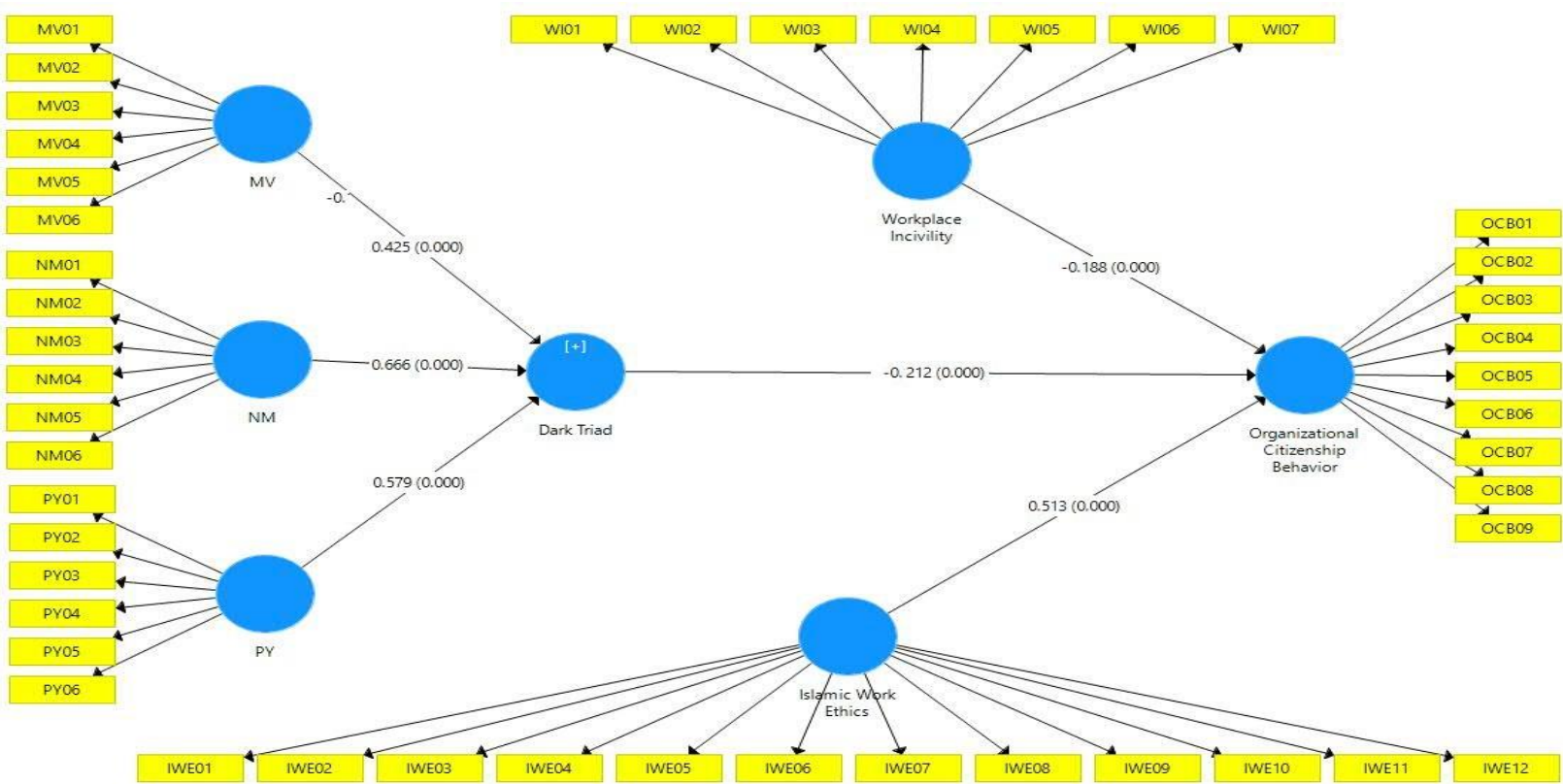

Figure 2. Model fitness (Smart-PLS-SEM)

Table 1 illustrates the correlational values of all variables of study where, DT positively and significantly associated with WPI $\left(r=.26^{* *}, p<.01\right)$ and negatively but significantly associated with IWE $\left(r=-.15^{* *}, p<.01\right)$ and OCB $\left(r=-.12^{* *}, p<.01\right)$. Whereas WPI significantly and negatively correlated with IWE $\left(r=-.11^{*}, p<.05\right)$ and OCB $\left(r=-.188^{* *}, p<.01\right)$. IWE is positively and significantly linked with OCB $\left(r=.34^{* *}, p<.01\right)$.

Table 1

Descriptive Statistics, Correlations and Reliabilities Statistics

\begin{tabular}{|c|c|c|c|c|c|c|c|}
\hline & & Mean & SD & 1 & 2 & 3 & 4 \\
\hline 1 & DT & 2.94 & .42 & (.65) & $.26^{* *} *$ & $-.15 * *$ & $-.12 * *$ \\
\hline 2 & WPI & 1.92 & .77 & & (.86) & $-.11 *$ & $-.18 * *$ \\
\hline 3 & IWE & 4.08 & .43 & & & (.67) & $.34 * *$ \\
\hline 4 & OCB & 4.14 & .52 & & & & (.84) \\
\hline
\end{tabular}

Note: DT, dark triad; WPI, workplace incivility; IWE, Islamic work ethics; OCB, organizational citizenship behavior; $* * \mathrm{p}<.01, * \mathrm{p}<.05 ; \mathrm{N}=$ 326

Table 2

Hierarchal Regression Analysis

\begin{tabular}{|c|c|c|c|c|c|c|c|c|}
\hline \multirow{3}{*}{ Variable } & \multicolumn{8}{|c|}{ Organizational Citizenship Behavior } \\
\hline & \multicolumn{2}{|c|}{ M-1 } & \multicolumn{2}{|c|}{ M-2 } & \multicolumn{2}{|c|}{ M-3 } & \multicolumn{2}{|c|}{ M-4 } \\
\hline & $\beta$ & $t$ & $\beta$ & $t$ & $\beta$ & $t$ & $\beta$ & $t$ \\
\hline Intercept & $4.31 * * *$ & 29.28 & $4.23 * * *$ & 17.45 & $4.29 * * *$ & 17.96 & $2.55 * * *$ & 7.43 \\
\hline Gender & 0.03 & .38 & 0.03 & 0.35 & 0.04 & 0.47 & 0.03 & 0.34 \\
\hline Age & 0.01 & .20 & 0.01 & 0.18 & -0.007 & -0.09 & -0.02 & -0.38 \\
\hline Edu & -0.03 & -1.16 & -0.03 & -1.16 & -0.03 & -1.10 & -0.04 & -1.38 \\
\hline Exp & -0.03 & -.99 & -0.03 & -0.98 & -0.02 & -0.70 & -0.01 & -0.33 \\
\hline DT & & & $-0.26^{* *}$ & 0.37 & $-0.19 * *$ & 1.32 & $-0.13^{* *}$ & 0.49 \\
\hline WPI & & & & & $-0.13 * * *$ & -3.61 & & \\
\hline IWE & & & & & & & $0.41 * * *$ & 6.60 \\
\hline$R^{2}$ & 0.02 & & 0.02 & & 0.06 & & 0.14 & \\
\hline Adjusted $R^{2}$ & 0.01 & & 0.008 & & 0.04 & & 0.12 & \\
\hline$F$ & 1.89 & & $1.54 * *$ & & $3.51 * *$ & & $8.71 * * *$ & \\
\hline
\end{tabular}

For mediation analysis, we followed the methods recommended by Sobel (1982), Hayes (2018), and Baron and Kenny (1986). Table 3 illustrates the mediation results of the study, values of Sobel (1982) test showed that there was significant mediation of WPI (effect $=-.07, p<.05$ ). For further 
verification of results, through the bootstrapping (5000 sample) method of Hayes (2018), mediation effect was analyzed, where results indicated that there was mediation as there was no zero between the values of $95 \%$ CI ( $\beta=-.07, \mathrm{LL} / \mathrm{UL}=-13,-.03)$. Finally, Baron and Kenny (1986) analysis results also verified the results of first two tests, as indirect effect of WPI on OCB was significant, $(\beta=-.13, p<.001)$. Thus, $\mathrm{H}_{3}$ was approved.

Table 3

Mediation Analysis

\begin{tabular}{lccccc}
\hline Model & Effect & SE & $\mathrm{z}$ & LL \& UL CI (95\%) & $p$ \\
\hline Normal theory tests (Sobel) & -.07 & .03 & -2.41 & .02 \\
\hline Indirect (Hayes) & -.07 & .03 & & $-.13,-.03$ & .68 \\
\hline DT $\rightarrow$ OCB & .28 & .07 & & .00 \\
DT $\rightarrow$ WPI & .49 & .09 & .04 & .00 \\
WPI $\rightarrow$ OCB & -.13 & .04 & & \\
\hline Note: DT, dark triad; WPI, workplace incivility; IWE, Islamic work ethics; OCB, organizational citizenship behavior; Bootstrap sample size $=$ \\
5000; N= 326; LL, lower limit; UL, upper limit; CI, confidence
\end{tabular}

Figure 3 illustrates the mediation results which analyzed through the Smart-PLS algorithm method which also indicate that WPI mediates the relationship of DT and OCB, as all effects (direct, $\beta=.21, p<.001$, indirect, $\beta=-.36, p<.001$ ) was significant, which further supported the acceptance of $\mathrm{H}_{3}$ of this study.

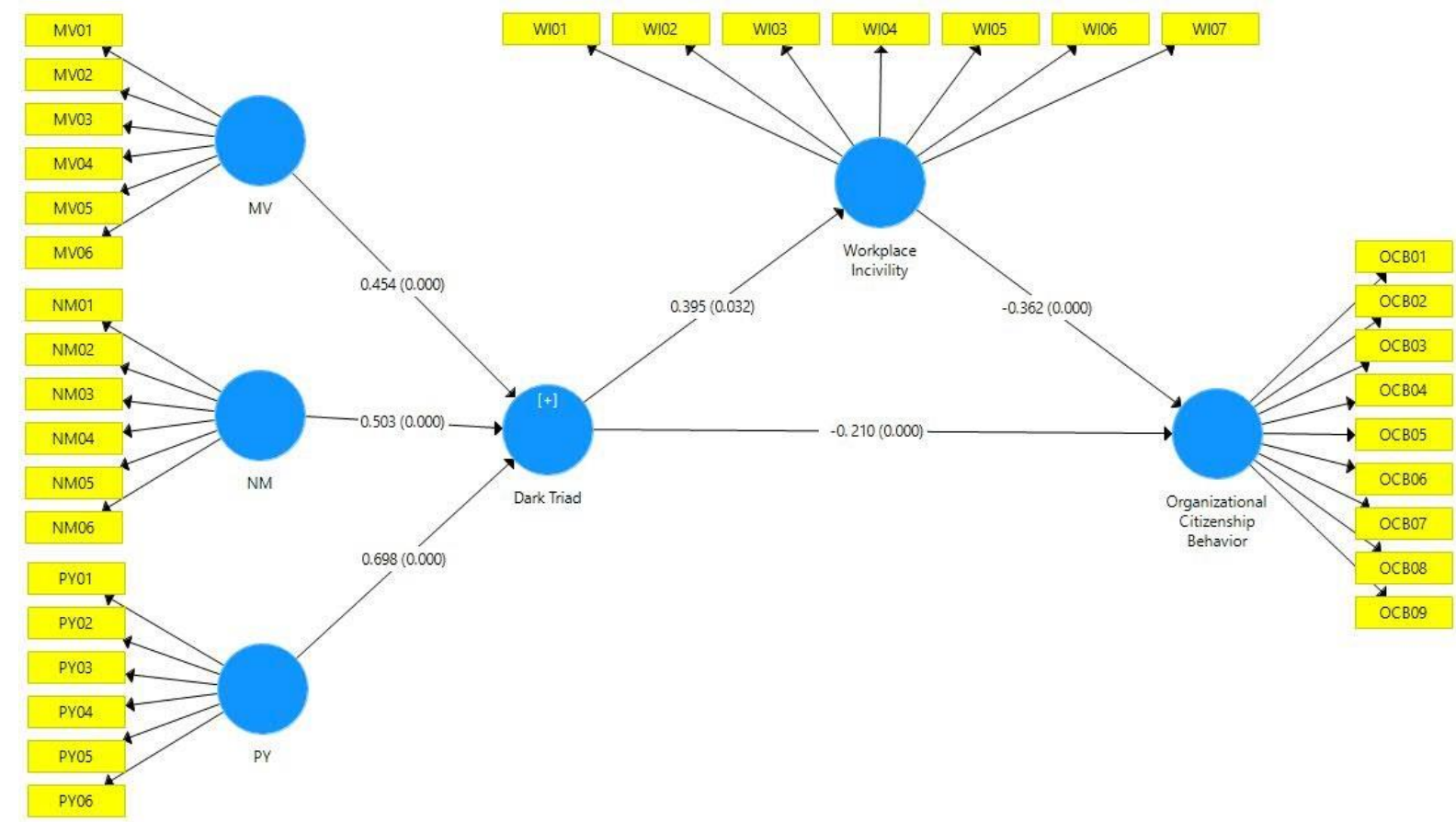

Figure 3. Indirect effects

Table 4 shows the moderation analysis of this study, where WPI significantly negatively influenced OCB $(\beta=-.11, p<.001)$ and IWE positively significantly influenced OCB $(\beta=.36, p$ $<.001)$ and interaction of WPI and IWE moderated the negative influence of WPI and OCB ( $\beta$ $=.34, p<.001$ ), which shows that higher level of IWE weakens the negative strength of the relationship between WPI and OCB. Thus, $\mathrm{H}_{4}$ was supported. 
Table 4

Moderation Analysis

\begin{tabular}{|c|c|c|c|}
\hline \multicolumn{4}{|c|}{ Moderation Model of Islamic Work Ethics } \\
\hline \multirow{2}{*}{ Variable } & \multicolumn{3}{|c|}{ Organizational Citizenship Behavior } \\
\hline & $\beta$ & $S E$ & $t$ \\
\hline Intercept & $4.35 * * *$ & .13 & 32.50 \\
\hline Gender & 0.04 & .08 & 0.55 \\
\hline Age & -0.04 & .06 & -0.61 \\
\hline Education & -0.05 & .03 & -1.81 \\
\hline Experience & 0.002 & .03 & 0.06 \\
\hline Workplace Incivility & $-0.11 * * *$ & .03 & -3.30 \\
\hline Islamic Work Ethics & $0.36^{* * * *}$ & .06 & 5.86 \\
\hline Workplace Incivility x Islamic Work Ethics & $0.33 * * *$ & .08 & 4.14 \\
\hline$R^{2}$ & 0.20 & & \\
\hline Adjusted $R^{2}$ & 0.18 & & \\
\hline$F$ & $11.723 * * *$ & & \\
\hline
\end{tabular}

Figure 4 demonstrates moderation interaction where a higher level of IWE weakens the intensity of workplace incivility on OCB.

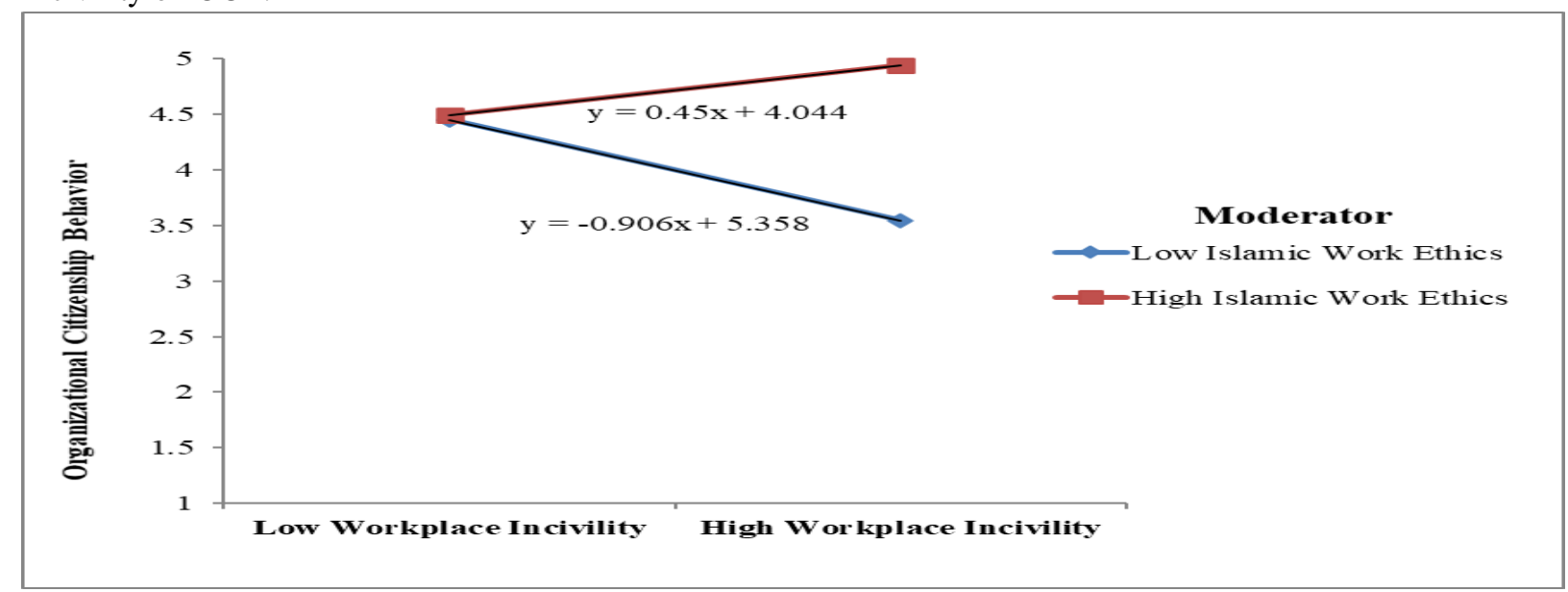

Figure 4. Moderation interaction

Figure 5 shows the moderation analysis results which was tested with the Smart-PLS bootstrapping (5000 sample) algorithm, which also verifies the moderation results of the earlier moderation method recommended by Hayes (2018).

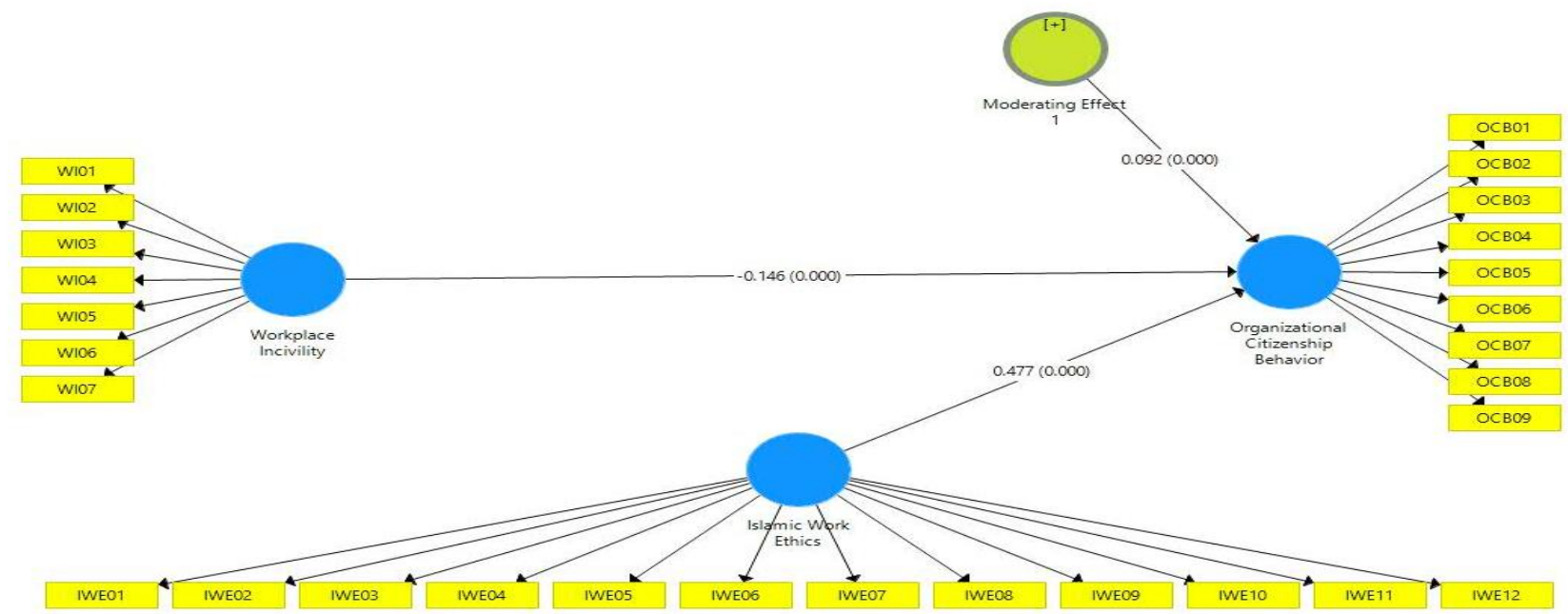

Figure 5. Moderation effects (Smart-PLS) 
Table 5 shows the moderated mediation results of this study (Index $=.14, S E=.06, \mathrm{LL} / \mathrm{UL}=$ $.04, .03)$, which shows that a higher level of IWE weakens the negative indirect effect of DT through WPI on OCB. Thus, it proved $\mathrm{H}_{5}$.

Table5

Index of Moderated Mediation

\begin{tabular}{lcccc}
\hline \multirow{2}{*}{ Mediator } & Moderator (IWE) & \multicolumn{2}{c}{ Organizational Citizenship Behavior } \\
\cline { 2 - 4 } \multicolumn{1}{c}{ WPI } & -.44 & CIE & SE (Boot) & LL \& UL CI (Boot) \\
& .44 & -.13 & .04 & $-.22,-.06$ \\
& \multicolumn{2}{c}{ Moderated Mediation Index } \\
Mediator (WPI) & \multicolumn{2}{c}{ Index } & SE (Boot) & LL \& UL (Boot) \\
\hline Moderator (IWE) & \multicolumn{1}{c}{.06} & .06 & $.06, .30$ \\
\hline $\begin{array}{l}\text { Note: DT, dark triad; WPI, workplace incivility; IWE, Islamic work ethics; OCB, organizational citizenship behavior; N = 326, CI, confidence } \\
\text { interval; CIE, conditional indirect effect; LL \& UL; lower limit and upper limit }\end{array}$
\end{tabular}

\section{Discussion}

The present research examined the impact of DT on OCB, with an intervening mechanism of WPI between the relationship of DT and OCB. Furthermore, the present study also examined the moderating role of IWE between the association of WPI and OCB. By using the lens of the theory of threatened egotism, the first hypothesis of this study that hypothesized that DT has a negative impact on OCB was supported. Earlier studies also prove the results of the present study (Spain et al., 2014; Webster \& Smith, 2019). The second hypothesis of this study proposed that WPI negatively influences the OCB was supported. Previous studies also prove the $\mathrm{H}_{2}$ (Karatepe et al., 2019; Liu et al., 2019; Taylor, Bedeian, \& Kluemper, 2012). The third hypothesis of the present study proposed that WPI intervenes in the negative association of DT and OCB. Findings of this study proved $\mathrm{H}_{3}$, which explains that dark personality holder individuals behave uncivil at the workplace with their supervisors, peers, and subordinates when they feel the threat to their ego from the environment of the organization, that resultantly reduce positive outcomes i.e., OCB (Abrar et al., 2014; Liu et al., 2019; Schilpzand et al., 2016; Taylor et al., 2012; Vahle-Hinz, Baethge, \& Van Dick, 2019). Furthermore, by using the lens of ECT (Victor \& Cullen, 1987, 1988), the fourth hypothesis of this study proposes that the ethical climate of the organization diminishes the intensity of negative personality and their uncivil behaviors. As IWE moderated the negative association of WPI and OCB, the findings of this study proved $\mathrm{H}_{4}$, which enlightens that IWE weakens the negative strength of the relationship between WPI and OCB. These findings are consistent with earlier studies that ethical climate of the organization (IWE) enforces individuals to demonstrate positive behaviors (Al-Arimi, Masrom, \& Mahmood, 2016; Chughtai, 2017; Hayati, Yuningsih, \& Caniago, 2018; Kareem \& bin Azmin, 2018; Kuncoro \& Wibowo, 2019; Sehhat et al., 2015). The final hypothesis of this study proposes the moderated mediation mechanism of IWE, and findings of the present study provided evidence for the acceptance of $\mathrm{H}_{5}$ of this study, as IWE weakens the indirect effect of DT on OCB via WPI. Higher degree of ethical climate of the organization (IWE) influences individuals' negative characteristics of personality, that further reduces the negative attitudes and uncivil behaviors and boost the OCB level at the workplace.

\section{Theoretical and Empirical Implications}

The present study contributes to organizational behavior and personality psychology in a few ways. First, this study investigated dark triad as an antecedent of workplace incivility which influenced the positive behavior of employees at the workplace. This study extends TTE (Baumeister \& Campbell, 1999; Baumeister et al., 1996) by investigating the indirect effect of WPI between the 
association of DT and OCB. When dark personality holder employees feel the threat to their ego from their supervisors, peers or subordinates, then they shelter their ego by demonstrating uncivil behavior. Moreover, this study contributes to the literature of work ethics by exploring the moderating role of IWE that proved that organizational climate holds the potential to weakens the intensity of negativity of personality and their negative behaviors. By incorporating ECT (Victor $\&$ Cullen, 1987, 1988), this study showed the moderated mediation link between the variables by identifying the interplay of IWE between the indirect effect of DT on OCB via WPI.

The present study has some practical implications for the organizations especially for the public sector organizations. First to overcome the intensity of uncivil behaviors of employees at the workplace, there is a need for personality and psychological tests during the phase of screening of candidates for the employment. Secondly, there is a need for awareness, on the job and off the job formal training about the ethics and how to control the negativity of the personality and uncivil behavior at the workplace. Thirdly, there is a need for strict implementation of policies without discrimination and with zero tolerance or favoritism against those employees who demonstrate the uncivil behavior and violate the norms, discipline of the organization at the workplace non-verbally or verbally. Finally, organizations without discrimination of culture (i.e., eastern, or western, public, or private) adopt and implement Islamic ethical code, as Islamic ethical code, and culture not only emphasizes cooperation at the workplace but also emphasizes the dedication of work (Arslan, 2000).

\section{Limitations and Future Research}

All variables of this study were assessed through a single source and self-report, especially for DT (Wu \& Lebreton, 2011), as self-evaluations are the most proper, convenient, and economical methods to assess the relationship of variables. It is challenging to recognize and openly report regarding the activities of the OCB and WPI of employees by self-reported assessment. Further research may collect data through time-lag or multiple sources (supervisor-rated or peer-rated) to assess the level of OCB and WPI of the individuals; that will not only help to reduce the common method variance but also provide in-depth clarification of data. Future research will be beneficial if data is collected from other public sector organizations of different cultural backgrounds, as for this study the data was collected from (judicial sector). In this study, IWE was used as a moderator as an ethical variable. Future research may investigate other variables as moderator i.e., leadership style, emotional intelligence, mindfulness, and occupational calling, to further explain how these variables influence the association of DT and WPI with OCB.

\section{Reference}

Abrar, M., Baig, S. A., Javed, M., \& Shabir, M. (2014). The contribution of workplace incivility and psychological capital towards organizational citizenship behavior. International Journal of Business and Behavioral Sciences, 4(6), 70-84.

Ahmad. (2011). Work ethics: an Islamic prospective. Journal of Human Sciences, 8(1), 850-859.

Ahmed, A., Arshad, M. A., Mahmood, A., \& Akhtar, S. (2019). The influence of spiritual values on employee's helping behavior: the moderating role of Islamic work ethic. Journal of Management, Spirituality \& Religion, 16(3), 235-263.

Akella, D., \& Lewis, V. J. (2019). The modern face of workplace incivility. Organization Management Journal, 1-6.

Al-Arimi, A. A. A., Masrom, M., \& Mahmood, N. H. N. (2016). The moderating effect of islamic work ethics on the relationship between knowlege management capabilities and organizational performance at the private higher education institutions in Oman. Journal of Theoretical and Applied Information Technology, 94(2), 396-407. 
Ali, A. J. (1992). The islamic work ethic in Arabia. The Journal of Psychology, 126(5), 507-519. ttps://doi.org/10.1080/00223980.1992.10543384

Ali, A. J., \& Weir, D. (2005). Islamic perspectives on management and organization. Cheltenham, UK: Edward Elgar Pub.

Andersson, L. M., \& Pearson, C. M. (1999). Tit for tat? The spiraling effect of incivility in the workplace. Academy of Management Review, 24(3), 452-471.

Annisaa Miranty, N., \& Wimbarti, S. (2014). The role of islamic work ethics as moderating variable in the relationsip between job demands and job resources to work engagement. Paper presented at the the Fifth International AAICP Conference on Stress, Health and Well-being: Indigenous, Social and Cultural Perspectives Universitas Sebelas Maret, Surakarta, Indonesia.

Arslan, M. (2000). A cross-cultural comparison of British and Turkish managers in terms of Protestant work ethic characteristics. Business Ethics: A European Review, 9(1), 13-19.

Bai, Q., Lin, W., \& Wang, L. (2016). Family incivility and counterproductive work behavior: A moderated mediation model of self-esteem and emotional regulation. Journal of Vocational Behavior, 94, 11-19.

Baron, R. M., \& Kenny, D. A. (1986). The moderator-mediator variable distinction in social psychological research: Conceptual, strategic, and statistical considerations. Journal of Personality and Social Psychology, 51(6), 1173-1182.

Baumeister, R. F., \& Campbell, W. K. (1999). The intrinsic appeal of evil: Sadism, sensational thrills, and threatened egotism. Personality and Social Psychology Review, 3(3), 210-221.

Baumeister, R. F., Smart, L., \& Boden, J. M. (1996). Relation of threatened egotism to violence and aggression: The dark side of high self-esteem. Psychological review, 103(1), 5-33.

Becker, J. A., \& Dan O'Hair, H. (2007). Machiavellians' motives in organizational citizenship behavior. Journal of Applied Communication Research, 35(3), 246-267.

Belschak, F. D., Den Hartog, D. N., \& Kalshoven, K. (2015). Leading Machiavellians: How to translate Machiavellians' selfishness into pro-organizational behavior. Journal of Management, 41(7), 1934-1956.

Bernard, H. R. (2017). Research methods in anthropology: Qualitative and quantitative approaches (3re (ed). ed.). Walnut Creek, CA: Alta Mira Press.

Blair, C. A., Hoffman, B. J., \& Helland, K. R. (2008). Narcissism in organizations: A multisource appraisal reflects different perspectives. Human Performance, 21(3), 254-276.

Boey, L., \& Vantilborgh, T. (2016). A theoretical model relating the dark triad of personality to the content of employees' psychological contracts. New Zealand Journal of Employment Relations, 40(3), 44-66.

Brankley, A. E., \& Rule, N. O. (2014). Threat perception: How psychopathy and Machiavellianism relate to social perceptions during competition. Personality and Individual Differences, 71, 103-107.

Brender-Ilan, Y., \& Sheaffer, Z. (2019). How do self-efficacy, narcissism and autonomy mediate the link between destructive leadership and counterproductive work behaviour. Asia Pacific Management Review, 24(3), 212-222.

Bunk, J. A., \& Magley, V. J. (2013). The role of appraisals and emotions in understanding experiences of workplace incivility. Journal of Occupational Health Psychology, 18(1), 87-105.

Bushman, B. J., \& Baumeister, R. F. (1998). Threatened egotism, narcissism, self-esteem, and direct and displaced aggression: Does self-love or self-hate lead to violence? Journal of Personality and Social Psychology, 75(1), 219.

Chen, \& Wang, C.-H. (2019). Incivility, satisfaction and turnover intention of tourist hotel chefs: Moderating effects of emotional intelligence. International Journal of Contemporary Hospitality Management, 31(5), 2034-2053.

Chughtai, M. S. (2017). Hrm Practices and Employee's Performance: Moderating Role of Islamic Work Ethics and Mediating Role of Hr Outcomes in Judiciary of Punjab, Pakistan. Virtual University of Pakistan.

Cohen, A. (2016). Are they among us? A conceptual framework of the relationship between the dark triad personality and counterproductive work behaviors (CWBs). Human Resource Management Review, 26(1), 69-85.

Cortina, L. M., \& Magley, V. J. (2009). Patterns and profiles of response to incivility in the workplace. Journal of Occupational Health Psychology, 14(3), 272-288.

Cortina, L. M., Magley, V. J., Williams, J. H., \& Langhout, R. D. (2001). Incivility in the workplace: incidence and impact. Journal of Occupational Health Psychology, 6(1), 64.

Costello, B. J., \& Dunaway, R. G. (2003). Egotism and delinquent behavior. Journal of Interpersonal Violence, 18(5), 572-590.

Dahling, Whitaker, B. G., \& Levy, P. E. (2009). The development and validation of a new Machiavellianism scale. Journal of Management, 35(2), 219-257.

Douglas, S. C., \& Martinko, M. J. (2001). Exploring the role of individual differences in the prediction of workplace aggression. Journal of Applied Psychology, 86(4), 547-559.

Etikan, I., Musa, S. A., \& Alkassim, R. S. (2016). Comparison of convenience sampling and purposive sampling. American journal of theoretical and applied statistics, 5(1), 1-4. 
Finkelstein, S., Cannella, S. F. B., Hambrick, D. C., \& Cannella, A. A. (2009). Strategic leadership: Theory and research on executives, top management teams, and boards. USA: Oxford University Press.

Furnham, A., Richards, S. C., \& Paulhus, D. L. (2013). The Dark Triad of personality: A 10 year review. Social and Personality Psychology Compass, 7(3), 199-216.

Garcia, D., \& Rosenberg, P. (2016). The dark cube: dark and light character profiles. PeerJ, 4 , e1675. https://doi.org/10.7717/peerj.1675

Gheitani, A., Imani, S., Seyyedamiri, N., \& Foroudi, P. (2019). Mediating effect of intrinsic motivation on the relationship between Islamic work ethic, job satisfaction, and organizational commitment in banking sector. International Journal of Islamic and Middle Eastern Finance and Management, 12(1), 76-95. https://doi.org/10.1108/IMEFM-01-2018-0029

Glasø, L., Vie, T. L., Holmdal, G. R., \& Einarsen, S. (2010). An application of affective events theory to workplace bullying. European Psychologist, 16(3), 198-208.

Hart, W., Adams, J. M., \& Tortoriello, G. (2017). Narcissistic responses to provocation: An examination of the rage and threatened-egotism accounts. Personality and Individual Differences, 106, 152-156.

Hayati, K., Yuningsih, Y., \& Caniago, I. (2018). Can Islamic work ethics and ethical climate reduce counterproductive work behavior? International Journal of Economics, Business, and Entrepreneurship, 1(2), 95-101.

Hayes, A. F. (2018). Introduction to mediation, moderation, and conditional process analysis (Second Edition ed.). New York: The Guilford Press.

Hershcovis, M. S. (2011). "Incivility, social undermining, bullying... oh my!": A call to reconcile constructs within workplace aggression research. Journal of Organizational Behavior, 32(3), 499-519.

Hur, W. M., Kim, H., \& Woo, J. (2014). How CSR leads to corporate brand equity: Mediating mechanisms of corporate brand credibility and reputation. Journal of Business Ethics, 125(1), 75-86.

Jakobwitz, S., \& Egan, V. (2006). The dark triad and normal personality traits. Personality and Individual Differences, 40(2), 331-339.

Javaid, M., Abdullah, N. H., Zeb, A., \& Hussain, K. (2018). The impact of authentic leadership on knowledge sharing behavior with the moderating role of islamic work ethics. 1049(1), 1-11. https://doi.org/10.1088/1742-6596/1049/1/012007

Jonason, P. K., Li, N. P., Webster, G. D., \& Schmitt, D. P. (2009). The dark triad: Facilitating a short-term mating strategy in men. European Journal of Personality: Published for the European Association of Personality Psychology, 23(1), 5-18.

Jonason, P. K., Slomski, S., \& Partyka, J. (2012). The Dark Triad at work: How toxic employees get their way. Personality and Individual Differences, 52(3), 449-453.

Jonason, P. K., \& Webster, G. D. (2010). The dirty dozen: A concise measure of the dark triad. Psychological Assessment, 22(2), $420-432$.

Jonason, P. K., Wee, S., \& Li, N. P. (2015). Competition, autonomy, and prestige: Mechanisms through which the Dark Triad predict job satisfaction. Personality and Individual Differences, 72, 112-116.

Jones, \& Paulhus. (2009). Machiavellianism handbook of individual differences in social behavior. 72 Spring Street, New York: The Guilford Press.

Jones, \& Paulhus. (2011). The role of impulsivity in the Dark Triad of personality. Personality and Individual Differences, 51(5), $679-682$.

Jones, \& Paulhus. (2014). Introducing the short dark triad (SD3) a brief measure of dark personality traits. Assessment, 21(1), 2841.

Jones, \& Paulhus, D. L. (2010). Different provocations trigger aggression in narcissists and psychopaths. Social Psychological and Personality Science, 1(1), 12-18.

Jones, D. N., \& Figueredo, A. J. (2013). The core of darkness: Uncovering the heart of the Dark Triad. European Journal of Personality, 27(6), 521-531.

Judge, T. A., \& LePine, J. A. (2007). The bright and dark sides of personality: Implications for personnel selection in individual and team contexts. Research Companion to the Dysfunctional Workplace: Management Challenges and Symptoms, 332.

Judge, T. A., LePine, J. A., \& Rich, B. L. (2006). Loving yourself abundantly: relationship of the narcissistic personality to selfand other perceptions of workplace deviance, leadership, and task and contextual performance. Journal of Applied Psychology, 91(4), 762-776.

Kajonius, P. J., Persson, B. N., \& Jonason, P. K. (2015). Hedonism, achievement, and power: Universal values that characterize the Dark Triad. Personality and Individual Differences, 77, 173-178.

Karatepe, O. M., Kim, T. T., \& Lee, G. (2019). Is political skill really an antidote in the workplace incivility-emotional exhaustion and outcome relationship in the hotel industry? Journal of Hospitality and Tourism Management, 40, 40-49. 
Kareem, O., \& bin Azmin, A. A. (2018). The influence of Islamic work ethics on the magnitude of organizational culture's effect on SME performance in Nigeria: A Conceptual Framework. International Journal of Academic Research in Business and Social Sciences, 8(4), 11-23.

Karim, J., Bibi, Z., Rehman, S. U., \& Khan, M. S. (2015). Emotional intelligence and perceived work-related outcomes: Mediating role of workplace incivility victimization. Pakistan Journal of Psychological Research, 30(1), 21-37.

Khan, Abbas, M., Gul, A., \& Raja, U. (2015). Organizational justice and job outcomes: Moderating role of Islamic work ethic. Journal of Business Ethics, 126(2), 235-246. https://doi.org/10.1007/s10551-013-1937-2

Khan, \& Rasheed, F. (2015). Human resource management practices and project success, a moderating role of Islamic Work Ethics in Pakistani project-based organizations. International Journal of Project Management, 33(2), 435-445.

Konrath, S., Bushman, B. J., \& Campbell, W. K. (2006). Attenuating the link between threatened egotism and aggression. Psychological Science, 17(11), 995-1001.

Kuncoro, W., \& Wibowo, G. (2019). The Increase of organizational citizenship behaviour (OCB) through Islamic work ethics, affective commitment, and organizational identity. International Business Research, 12(2), 181-190.

Lane, S. D., \& McCourt, H. (2013). Uncivil communication in everyday life: A response to Benson's" The Rhetoric of Civility". Journal of Contemporary Rhetoric, 3(1/2), 17-29.

Lee, K., \& Allen, N. J. (2002). Organizational citizenship behavior and workplace deviance: The role of affect and cognitions. Journal of Applied Psychology, 87(1), 131-142.

LePine, J. A., Erez, A., \& Johnson, D. E. (2002). The nature and dimensionality of organizational citizenship behavior: a critical review and meta-analysis. Journal of Applied Psychology, 87(1), 52.

Lim, S., \& Cortina, L. M. (2005). Interpersonal mistreatment in the workplace: the interface and impact of general incivility and sexual harassment. Journal of Applied Psychology, 90(3), 483-496.

Lim, S., Cortina, L. M., \& Magley, V. J. (2008). Personal and workgroup incivility: Impact on work and health outcomes. Journal of Applied Psychology, 93(1), 95-107.

Liu, W., Zhou, Z. E., \& Che, X. X. (2018). Effect of Workplace incivility on OCB through burnout: The moderating role of affective commitment. Journal of Business and Psychology, 1-13.

Liu, W., Zhou, Z. E., \& Che, X. X. (2019). Effect of workplace incivility on OCB through burnout: the moderating role of affective commitment. Journal of Business and Psychology, 34(5), 657-669.

Mackenzie, S. B., Podsakoff, N. P., \& Podsakoff, P. M. (2018). Individual-and organizational-level consequences of organizational citizenship behaviors The oxford handbook of organizational citizenship behavior.

Mao, C., Chang, C.-H., Johnson, R. E., \& Sun, J. (2019). Incivility and employee performance, citizenship, and counterproductive behaviors: Implications of the social context. Journal of Occupational Health Psychology, 24(2), 213-227.

Martin, K. D., \& Cullen, J. B. (2006). Continuities and extensions of ethical climate theory: A meta-analytic review. Journal of Business Ethics, 69(2), 175-194.

Mathieu, C. (2013). Personality and job satisfaction: The role of narcissism. Personality and Individual Differences, 55(6), 650654.

Mathieu, C., Neumann, C. S., Hare, R. D., \& Babiak, P. (2014). A dark side of leadership: Corporate psychopathy and its influence on employee well-being and job satisfaction. Personality and Individual Differences, 59, 83-88.

Meier, L. L., \& Semmer, N. K. (2013). Lack of reciprocity, narcissism, anger, and instigated workplace incivility: A moderated mediation model. European Journal of Work and Organizational Psychology, 22(4), 461-475.

Michel, J. S., \& Bowling, N. A. (2013). Does dispositional aggression feed the narcissistic response? The role of narcissism and aggression in the prediction of job attitudes and counterproductive work behaviors. Journal of Business and Psychology, 28(1), 93-105.

Miner-Rubino, K., \& Reed, W. D. (2010). Testing a moderated mediational model of workgroup incivility: The roles of organizational trust and group regard. Journal of Applied Social Psychology, 40(12), 3148-3168.

Morf, \& Rhodewalt. (1993). Narcissism and self-evaluation maintenance: Explorations in object relations. Personality and Social Psychology Bulletin, 19(6), 668-676.

Morf, \& Rhodewalt. (2001). Unraveling the paradoxes of narcissism: A dynamic self-regulatory processing model. Psychological Inquiry, 12(4), 177-196.

Nasution, F. N., \& Rafiki, A. (2019). Islamic work ethics, organizational commitment and job satisfaction of Islamic banks in Indonesia. RAUSP Management Journal. https://doi.org/10.1108/RAUSP-01-2019-0011

Nielsen, M. B., Hetland, J., Matthiesen, S. B., \& Einarsen, S. (2012). Longitudinal relationships between workplace bullying and psychological distress. Scandinavian journal of work, environment \& health, 38-46. 
O’Boyle, E. H., Forsyth, D. R., Banks, G. C., \& McDaniel, M. A. (2012). A meta-analysis of the Dark Triad and work behavior: a social exchange perspective. Journal of Applied Psychology, 97(3), 557-579. https://doi.org/10.1037/a0025679. Epub 2011 Oct 24.

Öngen, D. E. (2010). Relationships between narcissism and aggression among non-referred Turkish university students. ProcediaSocial and Behavioral Sciences, 5, 410-415.

Organ, D. W. (1988). Organizational citizenship behavior: The good soldier syndrome. MA: Lexington: Lexington Books/DC Heath and Com.

Organ, D. W. (1997). Organizational citizenship behavior: It's construct clean-up time. Human Performance, $10(2), 85-97$.

Özsoy, E. (2018). Dark triad and counterproductive work behaviors: Which of the dark triad traits is more malevolent? Işletme Araştırmaları Dergisi, 10(4), 742-756.

Paulhus, D. L., \& Williams, K. M. (2002). The dark triad of personality: Narcissism, Machiavellianism, and psychopathy. Journal of Research in Personality, 36(6), 556-563.

Pearson, C. M., Andersson, L. M., \& Porath, C. L. (2000). Assessing and attacking workplace incivility. Organizational Dynamics, 29(2), 123-137.

Pearson, C. M., Andersson, L. M., \& Porath, C. L. (2005). Workplace incivility. In S. Fox \& P. E. Spector (Eds.), Counterproductive work behavior: Investigations of actors and targets (pp. 177-200). American Psychological Association.

Pearson, C. M., Andersson, L. M., \& Wegner, J. W. (2001). When workers flout convention: A study of workplace incivility. Human Relations, 54(11), 1387-1419.

Pearson, C. M., \& Porath, C. L. (2005). On the nature, consequences and remedies of workplace incivility: No time for "nice"? Think again. Academy of Management Perspectives, 19(1), 7-18.

Penney, L. M., \& Spector, P. E. (2002). Narcissism and counterproductive work behavior: Do bigger egos mean bigger problems? International Journal of Selection and Assessment, 10(1-2), 126-134.

Porath, \& Erez, A. (2009). Overlooked but not untouched: How rudeness reduces onlookers' performance on routine and creative tasks. Organizational Behavior and Human Decision Processes, 109(1), 29-44.

Porath, \& Pearson, C. (2013). The price of incivility. Harvard Business Review, 91(1-2), $115-121$.

Rashid, M. Z., \& Ibrahim, S. (2008). The effect of culture and religiosity on business ethics: A cross-cultural comparison. Journal of Business Ethics, 82(4), 907-917.

Raskin, R. N., \& Hall, C. S. (1979). A narcissistic personality inventory. Psychological Reports, 45(2), 590-590.

Rhee, S. Y., Hur, W. M., \& Kim, M. (2017). The relationship of coworker incivility to job performance and the moderating role of self-efficacy and compassion at work: The Job Demands-Resources (JD-R) Approach. Journal of Business and Psychology, 32(6), 711-726.

Rizk, R. R. (2008). Back to basics: an Islamic perspective on business and work ethics. Social Responsibility Journal, 4(1/2), 246254.

Robinson, S. L., Wang, W., \& Kiewitz, C. (2014). Coworkers behaving badly: The impact of coworker deviant behavior upon individual employees. Annual Review of Organizational Psychology and Organizational Behavior, 1(1), $123-143$.

Roeser, K., McGregor, V. E., Stegmaier, S., Mathew, J., Kübler, A., \& Meule, A. (2016). The Dark Triad of personality and unethical behavior at different times of day. Personality and Individual Differences, 88, 73-77.

Schilpzand, P., De Pater, I. E., \& Erez, A. (2016). Workplace incivility: A review of the literature and agenda for future research. Journal of Organizational Behavior, 37, S57-S88.

Schütte, N., Blickle, G., Frieder, R. E., Wihler, A., Schnitzler, F., Heupel, J., \& Zettler, I. (2018). The role of interpersonal influence in counterbalancing psychopathic personality trait facets at work. Journal of Management, 44(4), 1338-1368.

Sehhat, S., Ashena, M., \& Parsa, S. (2015). Positive psychological capital: The role of Islamic work ethics in Tehran Public Organizations. Iranian journal of management studies, 8(4), 545-566.

Setar, S. B., Buitendach, J. H., \& Kanengoni, H. (2015). The moderating role of psychological capital in the relationship between job stress and the outcomes of incivility and job involvement amongst call centre employees. SA Journal of Industrial Psychology, 41(1), 13 pages. https://doi.org/10.4102/sajip.v41i1.1183

Sguera, F., Bagozzi, R. P., Huy, Q. N., Boss, R. W., \& Boss, D. S. (2016). Curtailing the harmful effects of workplace incivility: The role of structural demands and organization-provided resources. Journal of Vocational Behavior, 95, $115-127$.

Shamsudin, A. S., Rahman, H. A., \& Romle, A. R. (2015). The moderating of Islamic work ethic on relationship of emotional intelligence and leadership practice: A proposed framework. International Journal of Innovation, Management and Technology, $6(2), 140-143$

Shin, Y., \& Hur, W.-M. (2019). Linking flight attendants' job crafting and OCB from a JD-R perspective: A daily analysis of the mediation of job resources and demands. Journal of Air Transport Management, 79, 101681. https://doi.org/10.1016/j.jairtraman.2019.101681 
Smith, Craig Wallace, J., \& Jordan, P. (2016). When the dark ones become darker: How promotion focus moderates the effects of the dark triad on supervisor performance ratings. Journal of Organizational Behavior, 37(2), 236-254.

Smith, \& Lilienfeld, S. O. (2013). Psychopathy in the workplace: The knowns and unknowns. Aggression and Violent Behavior, 18(2), 204-218.

Sobel, M. E. (1982). Asymptotic Confidence Intervals for Indirect Effects in Structural Equation Models. Sociological Methodology, 13, 290. https://doi.org/10.2307/270723

Spain, S. M., Harms, P., \& LeBreton, J. M. (2014). The dark side of personality at work. Journal of Organizational Behavior, 35(S1), S41-S60.

Taylor, S. G., Bedeian, A. G., \& Kluemper, D. H. (2012). Linking workplace incivility to citizenship performance: The combined effects of affective commitment and conscientiousness. Journal of Organizational Behavior, 33(7), 878-893.

Turnipseed, D. L., \& Landay, K. (2018). The role of the dark triad in perceptions of academic incivility. Personality and Individual Differences, 135, 286-291.

Vahle-Hinz, T., Baethge, A., \& Van Dick, R. (2019). Beyond one work day? A daily diary study on causal and reverse effects between experienced workplace incivility and behaving rude towards others. European Journal of Work and Organizational Psychology, 28(2), 272-285.

Victor, B., \& Cullen, J. B. (1987). A theory and measure of ethical climate in organizations. Research in Corporate Social Performance and Policy, 9(1), 51-71.

Victor, B., \& Cullen, J. B. (1988). The organizational bases of ethical work climates. Administrative Science Quarterly, 101-125.

Wahab, M. A., Quazi, A., \& Blackman, D. (2016). Measuring and validating Islamic work value constructs: An empirical exploration using Malaysian samples. Journal of Business Research, 69(10), 4194-4204.

Wang, Y. D., \& Hsieh, H. H. (2013). Organizational ethical climate, perceived organizational support, and employee silence: A cross-level investigation. Human Relations, 66(6), 783-802.

Weaver, G. R., \& Agle, B. R. (2002). Religiosity and ethical behavior in organizations: A symbolic interactionist perspective. Academy of Management Review, 27(1), 77-97.

Webster, B. D., \& Smith, M. B. (2019). The Dark Triad and organizational citizenship behaviors: the moderating role of high involvement management climate. Journal of Business and Psychology, 34(5), 621-635.

Welbourne, J. L., \& Sariol, A. M. (2017). When does incivility lead to counterproductive work behavior? Roles of job involvement, task interdependence, and gender. Journal of Occupational Health Psychology, 22(2), 194-206.

Wiebe, K. F., \& Fleck, J. R. (1980). Personality correlates of intrinsic, extrinsic, and nonreligious orientations. The Journal of Psychology, 105(2), 181-187.

Wille, B., De Fruyt, F., \& De Clercq, B. (2013). Expanding and reconceptualizing aberrant personality at work: Validity of fivefactor model aberrant personality tendencies to predict career outcomes. Personnel Psychology, 66(1), 173-223.

Wisse, B., \& Sleebos, E. (2016). When the dark ones gain power: perceived position power strengthens the effect of supervisor Machiavellianism on abusive supervision in work teams. Personality and Individual Differences, 99, 122-126.

Wu, J., \& Lebreton, J. M. (2011). Reconsidering the dispositional basis of counterproductive work behavior: The role of aberrant personality. Personnel Psychology, 64(3), 593-626.

Yang, F. H., Tsai, Y. S., \& Tsai, K. C. (2014). The influences of ethical climate of turnover intention: The mediation role of emotional exhaustion. International Journal of Organizational Innovation, 6(4), 72-89.

Yen, C. H., \& Teng, H. Y. (2013). The effect of centralization on organizational citizenship behavior and deviant workplace behavior in the hospitality industry. Tourism Management, 36, 401-410.

Yousef. (2001). Islamic work ethic - A moderator between organizational commitment and job satisfaction in a cross-cultural context. Personnel Review, 30(2), 152-169.

Zagenczyk, T. J., Restubog, S. L. D., Kiewitz, C., Kiazad, K., \& Tang, R. L. (2014). Psychological contracts as a mediator between Machiavellianism and employee citizenship and deviant behaviors. Journal of Management, 40(4), 1098-1122. 